\title{
Coordination of Fiscal with Monetary and Financial Stability Policies Can Better Cure Unemployment
}

\author{
Philip Arestis, Cambridge Centre for Economic and Public Policy, Department of Land \\ Economy, University of Cambridge, UK
}

\begin{abstract}
This paper examines recent theoretical and empirical developments on fiscal policy to conclude that it is an effective macroeconomic tool in terms of curing unemployment. It is further shown that financial stability, ignored prior to the 'great recession', is important in economic policy. Fiscal policy can contribute to curing unemployment, especially so when coordinated closely not only with monetary policy but also with financial stability policies. We also suggest that such coordination should be geared towards reducing income inequality. It is then high time that economists and economic-policy makers turned their attention more closely and seriously to restoring faith in fiscal policy with its strong macroeconomic role as a means of curing unemployment. Fiscal policy, properly coordinated with monetary and financial stability policies, should thereby be restored to its proper upgraded role in terms of economic policy.
\end{abstract}

\section{JEL Classification: E62, H30}

Keywords: fiscal policy, unemployment, coordination of fiscal, monetary and financial stability policies, income inequality

\section{Introduction}

The purpose of this paper is to argue that fiscal policy can cure unemployment, which is linked to aggregate demand. When aggregate demand falls short of the economy's ability to supply goods and services, unemployment rises. As the aggregate demand increases unemployment is reduced. Governments can stimulate aggregate demand when it is too weak and can restrain it when it is too strong. In this process fiscal policy influences positively output and income, reduces inequality, improves human capital, and has immeasurable social benefits. Such role and benefits, however, can better be achieved if there is proper coordination between fiscal policy, monetary and financial stability policies. ${ }^{1}$ Interestingly enough, the 'great recession' has highlighted not only the importance of fiscal policy but also that of financial stability. Both had been downgraded prior to the 'great recession'. In terms of financial stability the belief in the efficiency of financial markets prevented a realistic and necessary approach to it by the supporters of the New Consensus Macroeconomics (NCM) framework; as a result systemic risk, financial regulation and supervision were significantly downgraded (see, for example, Arestis, 2011, 2012; Arestis and Karakitsos, 2013, for more details). The focus of this contribution is on the strong potential of fiscal policy to cure

\footnotetext{
${ }^{1}$ This contribution draws on Arestis (2012) but it goes further in its focus in that it is concerned with the influence of fiscal policy on unemployment via its impact on aggregate demand. It also accounts for more recent and further contributions than the Arestis (op. cit.) study.
} 
unemployment, which is enhanced when coordinated with monetary and financial stability policies.

We proceed after this short introduction with theoretical developments on the effectiveness of fiscal policy, which are discussed in section 2. Empirical developments on fiscal policy are examined in section 3, where the strong role of fiscal policy and its coordinated role with monetary policy are discussed. Further policy coordination aspects, namely financial stability and policies to reduce income inequality, are discussed in section 4. A final section 5 summarises and concludes.

\section{Fiscal Policy Can Cure Unemployment: Theoretical Propositions}

Recent theoretical developments on fiscal policy reinstate its positive dimension, which had been downgraded by the proponents of the New Consensus Macroeconomics (NCM) paradigm. Auerbach et al. (2010) suggest that "This array of arguments against activist fiscal policy clearly met its match during the Great Recession ..... But it is not accurate to say that activist fiscal policy was totally discredited or unpractised in the period just before" (p. 143). Especially so, when relaxing the 'unrealistic' assumptions of the theoretical model of the NCM. The assumptions just referred to relate to the Ricardian economic agents who are those that behave in an optimizing, fully forward manner, by trading in asset and other markets and are, thus, able to smooth consumption over time. Non-Ricardian economic agents follow nonoptimizing simple rules of thumb (they do not optimize intertemporally or intratemporally), cannot and do not participate in asset markets, and they merely consume their net-of-tax disposable income. There is actually empirical evidence that supports the contention that a significant proportion of consumers and firms are actually non-Ricardian in that they are not forward-looking or their behaviour is constrained (Coenen et al., 2012). The presence of nonRicardian households is crucial in that fiscal policy is effective under these circumstances, even under the remit of the NCM theoretical framework (Coenen and Straub, 2005).

Such changes produce favourable results for fiscal policy in terms of its ability to cure unemployment. Blinder (2006) refers to a number of such assumptions of the NCM. These are long-time horizons, perfect foresight, rational expectations, perfect capital markets, and the absence of liquidity constraints. Removing such unrealistic assumptions does reaffirm the positive role of fiscal policy in curing unemployment. In terms of the assumption of liquidityunconstrained households and firms the evidence is clear. Even in developed countries up to a third of households do not have sufficient access to financial markets. Liquidity-constrained households and firms is thereby a great deal more realistic assumption and fully supported by the available evidence (Botman and Kumar, 2006). The assumption of overlapping generations is another 'unrealistic' assumption, relaxation of which produces a short-planning horizon by households implying that intertemporal smoothing of consumption is not possible (see, for example, Botman and Kumar, op. cit.). The study by Anderson, Hunt and Snudden (2013) is very relevant in terms of this argument. It uses a multicounty Dynamic Stochastic General Equilibrium (DSGE) model (the IMF Global Integrated Monetary and Fiscal Model, GIMF, which is described in Anderson et al., 2013), and drops some of these assumptions. More specifically, it assumes instead, liquidity-constrained households along with finite planning horizons of households (assumptions that are not adopted for the purposes of the 
NCM theoretical framework). In utilising these assumptions this study produces interesting empirical results in that it demonstrate clearly that fiscal and monetary policies have an important role to play in economic policy. The study by Coenen et el. (2012) is also relevant in this regard. This is based on the argument that "rather than assuming that all households are Ricardian 'permanent income' consumers", it should be stated that "a significant fraction of households is liquidity-constrained, or follows rule-of-thump behaviour" (p. 24). This is very supportive of fiscal policy as a stabilization instrument. Ramey (2011) offers an interesting brief review of "the leading theories on the effects of government spending" ( $p$. 674 ) to conclude that "the theoretical work on government spending gives a wide range of possible values of the multiplier, depending on the type of model used, the assumptions about how monetary policy behaves, the type and persistence of government spending, and how it is financed" (p. 676). It is, therefore, suggested that "It is necessary ... to turn to the data to see if we can narrow the range" (p. 676). As stated below the empirical evidence reported in the Ramey (op. cit.) study provides a range of multipliers between 0.8 and 1.5.

A recent development that downgrades fiscal policy is that of fiscal austerity. It is argued that fiscal austerity is an important strategy to restore growth and employment. The argument is based on the proposition that reducing government deficit and public debt produce lower interest rates than otherwise, inject confidence in the private sector and thereby encourage more investment and consumption. The interesting question is why in a depressed economy investment and consumption would expand. Is it not the case that fiscal austerity leads to a short-run reduction in output and employment, which is often associated with a decline in the wage share and lower consumption. This produces an increase in income inequality, given the relatively high share of wages in the incomes of lower-income groups. The duration and magnitude of these effects depend on the size of automatic stabilizers, as well as the growth response and its impact on employment. If multipliers are especially high during downturns, fiscal contraction can have a strong effect on employment. The interesting question is where demand would emerge under such circumstances. Clearly countercyclical fiscal policy is the only option. One might refer to a relevant recent study to make the point. Baum et al. (2012) have shown that fiscal stimulus is more effective and austerity more disastrous during recessions than during output upswings. Fiscal austerity does not seem to have any theoretical or empirical backing.

These contributions relate to closed economies. The case of open economies should be, and has been, accounted for and interesting results emerge. Clearly, in the open economy case, trade balance and exchange rate changes could affect the value of the fiscal multiplier, in view of the leakages involved; the openness of the economy may very well lower multipliers. The size of the leakage would depend crucially on a number of factors that relate to the openness of the economy. Coenen et al. (2012) refer to the cases of the US and Europe to show that fiscal multipliers in the US are larger than in Europe, simply because the latter is a more open economy with larger leakages to imports. Although the reported open economy multipliers are weaker than in the case of a closed economy, they are certainly not negative. It is the case then that open economy multipliers favour fiscal policy (Gravelle and Hungerford, 2011). 
We next turn to the proposition that fiscal policy should not be implemented in isolation to monetary policy. Fiscal policy should be properly co-ordinated with monetary policy. Monetary policy reaction can play a key role in terms of the effectiveness of fiscal policy. When monetary and fiscal policies are consistent so that their impact on aggregate demand is cumulative, and not offsetting, the overall impact is higher than otherwise. Linnemann and Schabert (2003) utilize a model of wage and price stickiness to demonstrate that fiscal policy can affect output significantly if the monetary authority does not react aggressively to output changes.

Eggertsson (2006) suggests a concrete channel of fiscal expansion under coordination with monetary policy (see, also, Eggertsson, 2009). Fiscal expansion enhances expectations about future inflation, and, provided the central bank collaborates with the fiscal authority, the real rate of interest is reduced, which stimulates spending. It is important, though, in this approach, for the monetary authority to trade off some inflation for lower unemployment. Under such possibility a fiscal stimulus that increases inflationary pressures and a monetary authority that keeps constant the nominal interest rate, produces a lower real interest rate, thereby giving rise to further increases in consumption and investment expenditures. Also, a lower real interest rate causes the real exchange rate to depreciate, which can play a role in stimulating aggregate demand. ${ }^{2}$

\section{Fiscal Policy Can Cure Unemployment: Empirical Verification}

\subsection{Empirical Evidence without Coordination}

A number of empirical studies advocate renewed emphasis on fiscal policy as a key economic tool in macroeconomic stabilization. Romer and Romer (2010) is an example where a multiplier of roughly 3 is found for the US after three years of the fiscal change. Two recent IMF studies are also favourable to fiscal policy. The first (IMF, 2012b) suggests that "In the current recessionary context, the negative impact of fiscal adjustment on activity can be expected to be large, as confirmed by new work on the size of fiscal multipliers during periods of weak economic activity" (p. ix). The second study (Baunsgaard et al., 2012) concentrates on results produced and summarised by IMF (2012b) to argue that "fiscal multipliers ..... can for many reasons be expected now to be above the average multipliers identified in earlier studies (p. 15). ${ }^{3}$ Ramey (2011) offers a review of fiscal multipliers, based on US data and studies, and assesses the value of the multipliers as a result of a temporary, deficit-financed increase in government purchases, to conclude that the multiplier for this type of spending is probably between 0.8 and 1.5; it is also suggested that "Reasonable people can argue, however, that the data do not reject 0.5 or 2.0 " (p. 673). Coenen et al.

\footnotetext{
2 In the case of independent monetary and fiscal authorities, coordination of fiscal and monetary policy does not necessarily imply that the respective authorities need to lose their 'independence'. This is possible so long as both fiscal and monetary authorities have a common objective - for example maximization of social welfare (Eggertsson, 2006). Under such arrangements, both authorities would have to agree on the variables to be included in the social welfare function and the nature of trade-offs between the objectives.

3 Another IMF study, Estevão and Samake (2013), reports empirical results on fiscal consolidation, utilizing annual data from 1972 to 2010. Although fiscal consolidation tends to have a positive effect in low income countries, the results of fiscal consolidation in the case of advanced and emerging market economies confirm that it hurts short- and medium-term output.
} 
(2012) provide a summary of further studies on the same theme where significant fiscal policy multiplier effects are reported.

Gravelle and Hungerford (2011) provide a summary of fiscal policy multipliers of a number of recent studies. They suggest the following: "multipliers of 1.0 to 2.5 for government spending and transfers to the states for infrastructure, and 0.7 to 1.8 for transfers to the states for other purposes ..... For direct transfers to individuals (who have low incomes) the multipliers were between 0.8 and 2.1. Payments to retirees (largely Social Security beneficiaries) were 0.3 to 1.0 . For taxes, tax cuts for lower- and middle-income taxpayers ..... were 0.6 to 1.5 , while the increase in the alternative minimum tax exemption for higherincome individuals was 0.2 to 0.6 . Business tax cuts, mostly of a cash flow nature, were 0.0 to 0.4" (p. 6). Arestis and Sawyer (2012a), utilising the stock/flow consistency model as, for example, in Godley and Lavoie (2007) ${ }^{4}$ and estimated at the Levy Economics Institute of Bard College, report similar results. It should be noted, though, that the Arestis and Sawyer (2012a) reported multipliers are on the whole higher than the ones reported in Gravelle and Hungerford (2011).

An IMF study (Baum et al., 2012) examines whether there is a difference in multipliers in expansions and contractions. This study examines this possibility in the case of six out of the G-7 economies to conclude that average fiscal multipliers are larger in contractions than in expansions. This result is more prominent in the case of spending multipliers with the revenue multipliers not as high. Auerbach et al. (2010) and Auerbach and Gorodnichenko (2012) are studies that assess the effectiveness of fiscal policy, spawned by the Great Recession; they conclude that the size of fiscal multipliers differ in recessions and expansions. Auerbach and Gorodnichenko (op. cit.), in particular, use regime-switching, structural vector autoregression (SVAR), models and control for expectations, to conclude that government expenditure multipliers differ between recessions and expansions. In the case of the US economy, the derived multipliers vary from 1 to 1.5 in recessions and 0 to 0.5 in expansions. Blanchard and Perotti (2002) argue that in studying the quantitative impact of fiscal policy, the Structural VAR (SVAR) approach is more appropriate than large-scale econometric models or reduced-form ones. ${ }^{5}$ Employing post-war US data along with SVAR, the authors conclude that government purchases and tax multipliers for consumption and output are anything between one third and unity. Perotti (2012) concludes that higher tax multipliers than the ones in Blanchard and Perotti (2002) are in order. Perotti (2012) also concludes that, in contrast to the Ricardian Equivalence Theorem, there is no evidence of taxation anticipated effects.

\footnotetext{
${ }^{4}$ The conclusion of Godley and Lavoie (2007), in terms of the impact of fiscal policy in their model, is that "if the fiscal stance is not set in the appropriate fashion - that is, at a well-defined level and growth rate - then full employment and low inflation will not be achieved in a sustainable way" (p. 213).

${ }^{5}$ It should be noted, though, that the SVAR technique is not without its problems. As Auerbach et al. (2010) note: "a central concern with the structural vector autoregressive approach is the identification of policy shocks" (p. 149). Auerbach et al. (op. cit., pp. 149-150) also suggest that the SVAR approach is limited in view of its reduced-form nature. Three reasons are cited: automatic stabilisers cannot be accounted for; the SVAR approach cannot distinguish between short-lived and long-lived policies; and the derived multipliers can only account for the effects of policy interventions under the economic conditions as in the sample.
} 
The study by Gechert and Will (2012) employs Meta Regression analysis for 89 studies (published from 2007 onwards) and utilises data for the period 1992 to 2012 (thereby providing 749 observations in terms of multiplier values). The focus of this study is "to provide a systematic overview of the different approaches" in an attempt "to derive stylized facts and to separate structural form from method-specific effects" (p. 2). Although the authors agree with the contention that their method cannot provide "the true multiplier value" (p. 2), they are, nonetheless, in a position "to separate methodical distinctions among studies from structural distinctions of the fiscal policy settings these studies evaluate" (p. 2). Their conclusions are that their reported multipliers vary depending on the setting and method used. Even so, their derived multipliers are higher in the case of 'government expenditure' multipliers than the 'tax and transfers' ones; it should be noted, though, that these differences are not always significant. Another important result is that public investment portrays the strongest fiscal impulse. A further and very relevant result to our contribution is that the interest-rate reaction function is vital to the multiplier values. The latter are significantly higher when the monetary authorities accommodate fiscal policy or the zero-bound interest rate is in place.

The contribution by Pennings and Ruiz (2013) examines whether a speed of fiscal adjustment affects the size of fiscal multipliers. More precisely, their concern is whether once fiscal consolidation has been decided, would the pace to achieve it can affect the size of the multiplier. This is an empirical contribution, which portrays three features: the interaction between speed and consolidation size; a new sample of multi-year consolidations is constructed; and a new index is developed that measures the speed of the consolidation episodes as identified by the data. The latter is undertaken for 17 advanced countries over the period 1978-2009. Larger consolidation episodes produce multipliers of around 0.9, while for fast consolidations the multiplier could be as high as 1.8. The main conclusion of this contribution is that the speed at which fiscal consolidations are undertaken is important with fast consolidations producing higher multipliers than gradual consolidations. Pennings and Ruiz (op. cit.) acknowledge, however, that "Constrained by a small size, we see our results as a first step towards disentangling the relationship between speed and the multiplier, rather than the final word on the subject" (p. 19).

In't Velt (2003) focuses on the impact of fiscal consolidations in the core and periphery Euro Area (EA) countries over the period 2011-2013. Seven countries are examined separately (Germany, France, Spain, Portugal, Italy, Greece and Ireland) with the remainder EA countries examined as one aggregate block. The European Commission QUEST model (Ratto et al, 2008) is utilised for this purpose. Crisis conditions are assumed "with a higher share of households that are liquidity constrained than in normal times - set to half as opposed to 0.30.4 estimated over past periods - and interest rates constrained by their zero interest rate floor for the length of 4 years" (p. 1). The findings of this contribution suggest that "While average impact multipliers are in the range between $1 / 2$ and 1 , depending on the degree of openness, negative spillovers can add between $1 \frac{1}{2}$ and $2 \frac{1}{2}$ pps to the negative growth effects" (p. 18). It is also found that "Although the impact on current accounts is shown to be modest and it clearly cannot be a substitute for reforms in deficit countries, it would support growth in the core countries and spillovers to the periphery countries would ease their adjustment" (p. 18). 
A recent IMF (2013) study, which looks at lessons from the recent crisis on the role of fiscal policy in advanced economies, concludes that "The crisis has provided evidence that fiscal policy is an appropriate countercyclical policy tool when monetary policy is constrained by the zero lower bound, the financial sector is weak, or the output gap is particularly large" ( $p$. 1). Clearly coordination of fiscal and monetary policies is of vital importance as we argue further below. Still fiscal policy without coordination does matter. However, this leads to the obvious question of whether, and the extent to which, the available empirical evidence supports the proposition that when fiscal policy is coordinated with monetary policy can better cure unemployment. We discuss this issue in sub-section 3.2.

\subsection{Empirical Evidence with Coordination}

The empirical evidence is very supportive of coordinating fiscal and monetary policies. Eggertsson (2006), utilizing a calibrated model not dissimilar in substance to the NCM, reaches the conclusion that under fiscal and monetary policy coordination fiscal multipliers are higher than in the case of no coordination; they are, indeed, bigger than those found in the traditional Keynesian literature. Two types of fiscal multipliers are reported in Eggertsson (op. cit.): a real spending multiplier, where government consumption is raised but holding the budget balanced; and a deficit multiplier, where deficit spending increases. These fiscal multipliers are derived under two scenarios: when fiscal and monetary policies are coordinated; and when there is no policy coordination. ${ }^{6}$ The fiscal policy multiplier under coordination is 3.4 in the case of the real spending multiplier, and 3.8 under the deficit spending multiplier. When no policy coordination is present, i.e. when the central bank is 'goal independent', the real spending multiplier is unchanged, while the deficit spending multiplier is zero. Eggertsson (op. cit.) explains this important difference in fiscal multipliers, when coordination is present in relation to those where coordination is absent, by the expectations channel as discussed above in section 2 .

In another study Eggertsson (2011) utilises a two-state Markov-switching framework (designed for the econometric modelling of univariate and multiple time series subject to shifts in regime) to examine fiscal multipliers when monetary policy responds to the fiscal policy action, and when it does not as in the case of a zero lower bound. The conclusion is that fiscal multipliers are about five times higher at the zero lower bound than in the other more normal occasions. A relevant study by Woodford (2011) suggests that under conditions of 'zero-bound' nominal rate of interest, fiscal multipliers in excess of unity are possible. This could only happen when the task of monetary policy to fill the output gap generated by the falling real rate of interest, due to inflationary pressures, is undertaken by fiscal policy. Other, and some of them more recent, studies reach similar conclusions. For example, Christiano et al. (2011), Siesman and Watzka (2013) and Woodford (2010) show that government spending multipliers can be very large at zero bound; also increasing government expenditure is welfare improving. Blanchard et al. (2010) argue for a better integration between fiscal and monetary policy. Interestingly enough, Correira et al. (2013) argue that when the zero lower

\footnotetext{
${ }^{6}$ A different type of coordination is suggested by Sly and Weber (2013). This is fiscal coordination amongst economies, which become more integrated thereby influencing the transmission of macroeconomic shocks between them. Such fiscal coordination increases business cycle comovement by a one-and-a-half times larger than the effect of trade linkages of the relevant nations.
} 
bound on nominal interest rates is in place fiscal policy is the only alternative to provide stimulus in the economy. Employing a New Keynesian model, they argue for a tax policy, which can provide the stimulus. 'Wasteful public spending' they argue is an inefficient policy - but without justifying the inefficiency of such spending to stimulate the economy.

A number of studies utilize Dynamic Stochastic General Equilibrium (DSGE) models to deal with the question of fiscal and monetary policy coordination. DSGE models utilise a small number of equations, based on microeconomic theory with parameters from empirical estimates, which are calibrated to obtain their results. As such these models rely heavily on the modelling assumptions undertaken, which may not be valid (see, for example, Auerbach et al., 2010, p. 150). It is also the case that small changes in the assumed coefficients produce substantial changes in the estimated multipliers (Hall, 2009). Freedman et al. (2009), utilizing the IMF macroeconomic DSGE model, which includes non-Ricardian households, conclude that "the multipliers of a two-year fiscal stimulus package range from 1.3 for government investment to 0.2 for general transfers, with targeted transfers closer to the upper end of that range and tax cuts closer to the lower end. In the presence of monetary accommodation ... multipliers are up to twice as large, as accommodation lowers real interest rates, which in turn has a positive effect on corporate balance sheets and therefore on the external finance premium" (p. 26). Davig and Leeper (2009), utilizing a DSGE model, reach similar conclusions. This study concentrates on the experience of the 'great recession' when fiscal and monetary policies were used jointly in an effort to stimulate aggregate demand. The usual DSGE assumptions are utilized, with government expenditure treated as an exogenous variable. The study clearly concludes that coordination of the two policies provides stronger results than otherwise. Employing a number of structural DSGE models, ${ }^{7}$ Coenen et el. (2012) conclude that fiscal policy is most effective when monetary policy is accommodative; for "with monetary accommodation and nominal interest rates held constant, the increases in inflation give rise to decreases in real interest rates. As a result accommodative monetary policy complements the fiscal policy stimulus and intensifies its effects on real GDP” (p. 51).

Clearly, then, when fiscal policy is coordinated with monetary policy, it is more effective as the recent empirical evidence as reviewed above suggests.

\section{Fiscal Policy Can Cure Unemployment: Further Policy Coordination Possibilities}

The 'great recession' has highlighted the importance of financial stability, which had been ignored prior to it, mainly because of the firm belief and emphasis on the 'efficient market hypothesis' (EMH). The implication being that all unfettered markets clear continuously thereby making disequilibria, such as bubbles, highly unlikely (IMF, 2010b, 2012a). The belief in the efficiency of financial markets prevented a realistic and necessary approach to financial stability by both the supporters of the NCM framework and policymakers. As a result potential systemic risk was ignored and financial regulation, as well as supervision, was increasingly light-touch. Consequently, the role of financial stability and its policy

\footnotetext{
7 The models utilized are those developed at the Board of Governors of the Federal Reserve System (two models), the European Central Bank, the IMF, the European Commission, the Organisation for Economic Cooperation and Development (OECD), and the Bank of Canada.
} 
implications were downplayed significantly. However, the events leading to the 'great recession' testify to the important requirement of financial stability. The focus of financial stability should be on proper control of the financial sector so that it becomes socially and economically useful to the economy as a whole and to the productive economy in particular. Banks should serve the needs of their customers rather than provide short-term gains for shareholders and huge profits for themselves. Proposals that aim to ensure financial stability have been put forward and we have discussed these proposals in Arestis and Karakitsos (1013). As a result financial stability has attracted renewed interest and focus as an instrument of monetary policy (Arestis and Sawyer, 2012b). The IMF (2010a, 2010b) suggestion that financial stability in the form of both microprudential and macroprudential policies provides a definite and strong way forward (see, also, Arestis and Karakitsos, 2013, chapters 8 and 9). The same publications go further to suggest that if the current low interest rates were to produce excessive risk-taking or bubbles, these should be addressed through macro-prudential policies mainly and not only through interest rate policy measures. It is the case actually that only microprudential had been the basis of the regulatory framework prior to the 'great recession'. The difficulty with only a microprudential framework is that since it attempts to tackle problems with individual institutions, the overall result could very well be a serious damage to the economy as a whole.

It is, thus, paramount for a macroprudential to co-exist with a microprudential one. A number of writers have argued that the regulatory framework was problematic because of that deficiency and that macroprudential policies are thereby of enormous importance (see Hansen et al., 2011, and a number of additional references therein). Hansen et al. (op. cit.) summarise the argument very well: "A microprudential approach is one in which regulation is partial equilibrium in its conception and aimed at preventing the costly failure of individual financial institutions. By contrast, a 'macroprudential' approach recognizes the importance of general equilibrium effects, and seeks to safeguard the financial system as a whole. In the aftermath of the crisis there seems to be agreement among both academics and policymakers that financial regulation needs to move in a macroprudential direction" (p. 3). Macroprudential is a 'systemwide oversight' approach, and as such it "would broaden the mandate of regulators and supervisors to encompass consideration of potential systemic risks and weaknesses as well" (Bernanke, 2008). In terms of the macroprudential tools, Hansen et al. (2011) discuss six sets of such tools: time-varying capital requirements; higher-quality capital; corrective action targeted at capital as opposed to capital ratios; contingent capital; regulation of debt maturity; and regulating the shadow banking system. They offer empirical evidence to conclude that macroprudential regulation is of paramount importance. The danger is that "given the intensity of competition in financial services, they will also drive a larger share of intermediation into the shadow banking realm" (Hansen et al., p. 25). Regulating this system, long overdue in our view, along with the rest of the financial system is the obvious conclusion, although this is "a complex task, and one that will require a variety of specific tools" (Hansen et al., p. 25). Still such regulation is of vital importance, however complex such a task might be.

Angelini et al. (2012), utilising the DSGE model for the euro area, make the point that macroprudential policies interact with monetary policy in affecting asset prices and credit, thereby affecting the transmission mechanism of monetary policy. The relationship between 
the two policies, though, differs from country to country. The point that relates more closely to the main argument of this contribution is that macroprudential policy can improve macroeconomic stability, with the qualification that the results are negligible when the cycle relies on real supply shocks, but significant "in the presence of financial or sector specific shocks" (p. 26), along with the proposition that "lack of cooperation between a macroprudential authority and a central bank may actually generate conflicting policies, hence excessive volatility of the policy instruments (interest rates and capital requirements), without enhancing the stability of the key macroeconomic variables (output and the loans-tooutput ratio)" (p. 25). This leads Angelini et al. (op. cit.) to the conclusion that their "results suggest that the benefits of macroprudential policy depend on the shocks and on the degree of coordination with monetary policy" (p. 6); and that "Yet the interaction between the two has received surprisingly little attention" (p. 3).

These suggested measures have highlighted the importance and requirement for financial stability policies and the need to establish relevant and appropriate polices. BIS (2011) also makes the point when it suggests that "we need a stability framework in which monetary, fiscal and prudential policy work together to build a robust and stable macroeconomic and financial system that will make the next crisis both less likely and less severe" (p. 3). Another study, which also provides estimates of the effects of all the fiscal, monetary and financial interventions undertaken by the US government over the period since the beginning of the great recession, is Blinder and Zandi (2010). Using the Moody's Analytics model of the US economy, ${ }^{8}$ they estimate that in the absence of those programmes GDP and employment would have been lower by 11.5 percent and 8.5 percent respectively. They also produce estimates for the fiscal stimulus over the period, which amounts to an increase of GDP by 3.4 percent in 2010, equivalent to the creation of 2.7 million jobs. The paper by Medina and Roldós (2014) utilises a standard small open-economy New Keynesian model with a financial sector that incorporates financial frictions (a model that is essentially an extension of the financial accelerator of Bernanke et al., 1999). The introduction of financial frictions magnifies the cyclical fluctuations of the real and financial variables, especially so asset prices and credit. The model is used to investigate interactions between monetary and macroprudential policies. Macroprudential policies emerged during the great recession in a number of emerging countries in the form of raising reserve requirements to manage capital flows and curb credit growth, along with raising interest rates, in view of the unconventional monetary policies by the major 'reserve-currency-issuing' countries. The relevant conclusion of the Medina and Roldós (op. cit.) paper in terms of the purposes of this section is that employment of a macroprudential instrument is important but more so it is the close coordination of both macroprudential, which purports to mitigate financial frictions, and monetary policy, i.e. interest rate that can mitigate a nominal friction, that are shown to be "useful guidelines for the conduct of monetary policy in the context of volatile capital flows" (p. 32). ${ }^{9}$

8 For some details on the Moody's Analytics model of the US economy see: http://www.economy.com/home/products/us-macro-model.asp

${ }^{9}$ An interesting contribution that focuses on 'Macroprudential Policies in a Global Perspective' is the study by Jeanne (2014). It analyzes the case for international coordination of macroprudential policies with monetary policy in the context of a simple theoretical framework. The case of uncoordinated use of macroprudential policies can lead to a 'capital war', which can produce negative effects. The study's model examines the case where one country (the US) is in a liquidity trap with unemployment, while the rest of the world, China in this 
With the objective of financial stability, the Central Bank would become more like a Central Financial Agency (CFA). It would be responsible for policies, which seek to influence the credit and lending policies of the full range of financial institutions. Our current contribution in this context is to argue the case for full coordination of both monetary and financial stability policies with fiscal policy; such coordination is much more powerful in terms of the impact of fiscal policy on unemployment. We would go one step further and suggest that discretion is as important in applying them.

As argued in Arestis (2012), but also in Hein and Truger (2011), and Van Treeck and Sturn (2012), such coordination should also include another policy objective of paramount importance; namely cure socio-economic inequalities. This has become particularly relevant and important in policy making in view of the 'great recession'; one might go a step further and suggest that inequality has become a most important challenge of the current century. Indeed, the main causes that had lead to the 'great recession' demonstrated vividly that distribution of income if not tackled can lead to crisis. Distribution of income from wages to profits, especially to the top end, namely the financial sector, along with financial liberalisation and the financial architecture that followed was one of the main causes of the 'great recession' (Arestis and Karakitsos, 2011; 2013; see, also, Palley, 2010). As also argued in Arestis and Sawyer (2011) accounting for 'distributional effects' in both economic theory and policy, which have been fatally ignored in the past, has become a very serious consideration. An IMF Discussion Note (Berg and Ostry, 2011) also supports the view that income inequality and economic growth are closely related. The emphasis in the latter contribution is that what is particularly critical is that improving income distribution increases the length of growth spells rather than merely getting growth to take place. Clearly, such policies would contribute significantly to curing unemployment.

Another recent IMF contribution on income inequality (Ball et al., 2013) reaches similar conclusions. Fiscal consolidation produces significant, sizeable and persistent distributional effects. Ball et al. (op. cit.) employ 'impulse response functions directly from local projections' in a sample of 17 OECD countries, and using annual data for the period 19782009 , the authors conclude that fiscal consolidation raises inequality, decreases income shares and increases long-term unemployment significantly. Also government spendingbased programmes produce larger distributional effects than tax-based adjustments. ${ }^{10}$ Still another recent IMF paper (Woo et al., 2013) provides evidence on the effects of fiscal

sense, attempts to mitigate the effects of the US monetary stimulus by a prudential accumulation of reserves. A case for international coordination is proposed whereby both countries should be less aggressive in the pursuit of their objectives. It is also shown that "coordination is stronger in a bust when global resources are underutilized than in a boom" (p. 24). The study by Jeanne (op. cit.) adopts a view of macroprudential policy that is not restricted to banking regulation. In the case of the open economy macroprudential policy can be implemented through the management of international reserves.

${ }^{10}$ Fiscal consolidation as constructed in the Ball et al. (2013) study is "based on a narrative approach and focuses on policy actions - tax hikes and/or spending cuts - taken by governments with the intent of reducing the budget deficit" (p. 4). This differs from the "fiscal consolidation measured by successful budget outcomes" (p. 4; highlight as in the original). This latter measure of fiscal consolidation utilizes the cyclical primary balance, which is adjusted for the estimated effects of business cycle fluctuations. This measure of fiscal consolidation is thought by Ball et al. (op. cit.) to be problematic. 
consolidation on income inequality, for 17 OECD countries and for the period 1978-2009, using annual data. Econometric analysis for a panel of developed and emerging countries, along with twelve selected fiscal consolidation episodes, is utilised to conclude that fiscal consolidations raise inequality. Spending-based consolidations worsen significantly inequality relative to tax-based consolidations. Significant effects on unemployment are evident in this study; unemployment in its turn increases inequality, thereby providing an important channel through which consolidation increases inequality.

Our proposal of coordination of fiscal policy with monetary and financial stability policies, along with a serious emphasis on reducing income inequality, affects the level of demand in the economy through a higher wage share and a lower profits share. Sawyer (2010) gives examples to illustrate the case: "if the wage share were say 5 percentage points higher, and there is a difference in the marginal propensity to consume between wages and profits of say 0.3 , then savings would be lower by 1.5 percent of GDP. A redistribution of income from the top two deciles to bottom four deciles of 10 percent of earnings - that is 6 to 7 per cent GDP, and the marginal propensity to consume difference of 0.2 , a further 1.2 to 1.4 per cent; these two, rounded up to 3 per cent of GDP would solve much of the budget deficit problem. The shift from profits to wages in the first example would be the same order of magnitude (but in the opposite direction) as that observed in industrialised countries such as Germany over the past decade. The second example would amount similarly to the reversal of the inequality changes in the UK over the past three decades" (p. 42). These examples make the case for policies to tackle income distribution, which should be at the centre of the coordination of fiscal with monetary and financial stability policies as argued in this contribution. Such economic policies, with fiscal policy at the helm, influence aggregate demand and thereby unemployment. $^{11}$

\section{Summary and Conclusions}

We have argued in this paper that fiscal policy is an effective instrument of regulating the level of aggregate demand and thereby unemployment. We have examined this conclusion through both theoretical and empirical considerations to conclude that fiscal policy is a key component of any macroeconomic framework alongside monetary and financial policies. This conclusion is supported by a further suggestion, namely coordination of fiscal, monetary and financial stability policies. In doing so, the relevant authorities should employ a great deal of discretion in the application of this coordination.

It is the case, then, from our analysis in this contribution, that fiscal policy can cure unemployment through its impact on aggregate demand. Furthermore, this role of fiscal policy is further enhanced if there is proper coordination between fiscal policy, monetary and financial stability policies. Interestingly enough, the 'great recession' has highlighted not only the importance of fiscal policy but also that of financial stability. Both had been seriously downgraded prior to the 'great recession'. This contribution concludes that fiscal policy is a strong tool of economic policy in curing unemployment, especially so when

\footnotetext{
${ }^{11}$ A recent IMF (2014) study provides a list of fiscal policies that can produce 'more efficient' redistribution of income in both developed and developing countries.
} 
coordinated with monetary and financial stability policies (see, also, BIS, 2011). Furthermore, and as our proposal of coordination of fiscal policy with monetary and financial stability policies suggests, it is also paramount that such coordination should be geared towards reducing income inequality. Such combination and focus of economic policies is very robust in terms of curing unemployment.

\section{References}

Anderson, D., Hunt, B., Kortelainen, M., Kumhof, M. Laxton, D., Muir, D., Mursula, S. and Snudden, S. (2013), "Global Integrated Monetary and Fiscal Model (GIMF) - Model

Properties”, IMF Working Paper WP/13/55, Washington DC: International Monetary Fund.

Anderson, D., Hunt, B. and Snudden, S. (2013), "Fiscal Consolidation in the Euro Area: How Much Pain Can Structural Reforms Ease?", IMF Working Paper WP/13/211, Washington DC: International Monetary Fund.

Arestis, P. (2011), "Keynesian Economics and the New Consensus in Macroeconomics", in E. Hein and E. Stockhammer (eds.), A Modern Guide to Keynesian Macroeconomics and Economic Policies, Edward Elgar: Cheltenham.

Arestis, P. (2012), "Fiscal Policy: A Strong Macroeconomic Role", Review of Keynesian Economics, Inaugural Issue, 1(1), 93-108.

Arestis, P. and Karakitsos, E. (2011), "An Analysis of the Causes of the 'Great Recession' and Some Policy Implications", in T. Niechoj, Ö. Onaran, E. Stockhammer, A. Truger and T. van Treeck (eds.), Stabilising an Unequal Economy? Public Debt, Financial Regulation, and Income Distribution, Marburg: Metropolis-Verlag.

Arestis, P. and Karakitsos, E. (2013), Financial Stability and the Aftermath of the Great Recession, Houndmills, Palgrave Macmillan: Houndmills, Basingstoke..

Arestis, P. and Sawyer, M. (2011), "Economic Theory and Policies: New Directions After Neo-Liberalism", in P. Arestis and M. Sawyer (eds.), New Economics as Mainstream Economics, Annual Edition of International Papers in Political Economy, Palgrave Macmillan: Houndmills, Basingstoke..

Arestis, P. and Sawyer, M (2012a), "The Effectiveness of Fiscal Policy in the Stock/Flow Levy Institute's Model”, in D.B. Papadimitriou and G. Zezza (eds.), Contributions in StockFlow Modelling: Essays in Honour of Wynne Godley, Palgrave Macmillan: Houndsmills, Basingstoke.:

Arestis, P. and Sawyer, M (2012b), "The 'New Economics' and Policies for Financial Stability”, International Review of Applied Economics, 26(2), 147-160.

Auerbach, A.J., Gale, W.G. and Harris, B.H. (2010), "Activist Fiscal Policy", Journal of Economic Perspectives, 24(4), 141-164.

Auerbach, A. J. and Gorodnichenko, Y. (2012), "Measuring the Output Responses to Fiscal Policy", American Economic Journal: Economic Policy, 4(2), 1-27. 
Ball, L, Furceri, D., Leigh, D. and Loungani, P. (2013), "The Distributional Effects of Fiscal Consolidation", IMF Working Paper WP/13/151, Washington DC: International Monetary Fund.

Bank of International Settlements (BIS) (2011), "Fiscal Policy and its Implications for Monetary and Financial Stability", BIS Papers, No. 59, December, Basel, Switzerland: Bank for International Settlements. Available at: http://ssrn.com/abstract=2002654

Baum, A., Poplawski-Ribeiro, M. and Weber, A. (2012), "Fiscal Multipliers and the State of the Economy", IMF Working Paper, Washington DC: International Monetary Fund.

Baunsgaard, T., Mineshima, A., Poplawski-Ribeiro, M. and Weber, M. (2012), "Fiscal Multipliers," in C. Cottarelli, P. Gerson, and A. Senhadji (eds.), Post-crisis Fiscal Policy, Washington DC: International Monetary Fund.

Berg, A.G. and Ostry, J.D. (2011), "Inequality and Unsustainable Growth: Tow Sides of the Same Coin", IMF Discussion Note, SDN/11/08, April, Washington, D.C.: International Moneatry Fund. Available at: http://www.imf.org/external/pubs/ft/sdn/2011/sdn1108.pdf

Bernanke, B.S. (2008), "Reducing Systemic Risk", Federal Reserve Bank of Kansas City Annual Economic Symposium, 22 August, Jackson Hole: Wyoming.

Bernanke, B.S., Gertler, M., and Gilchrist, S. (1999), "The Financial Accelerator in a Quantitiative Business Cycle Framework," in J.B. Taylor and M. Woodford (eds.). Handbook of Macroeconomics, Vol. 1, Elsevier: Amsterdam.

Blanchard, O. and Perotti, R. (2002), "An Empirical Characterization of the Dynamic Effects of Changes in Government Spending and Taxes on Output", Quarterly Journal of Economics, 117(2), 1329-1368.

Blanchard, O., Dell'Ariccia, G. and Mauro, P. (2010), "Rethinking Macroeconomic Policy", International Monetary Fund Staff Position Note SPN/10/3, Washington DC: International Monetary Fund.

Blinder, A. (2006), “The Case Against Discretionary Fiscal Policy”, in R.W. Kopcke, G.M.B. Tootell and R.K. Triest (eds.), The Macroeconomics of Fiscal Policy, MIT Press: London. Blinder, A.S. and Zandi, M. (2010), "How the Great Recession Was Brought to an End". Available at: http://www.economy.com/mark-zandi/documents/End-of-Great-Recession.pdf

Botman, D. and Kumar, M.S. (2006), "Fundamental Determinants of the Effects of Fiscal Policy", IMF Working Paper 06/72, Washington DC: International Monetary Fund.

Christiano, L., Eichenbaum, M. and Rebelo, S. (2011), "When Is the Government Spending Multiplier Large?” Journal of Political Economy, 119 (1), 78-121.

Coenen, G., Erceg, C.J., Freeman, C., Furceri, D., Kumhof, M., Lalonde, R., Laxton, D., Lindé, J., Mourougane, A., Muir, D., Mursula, S., de Resende, C., Roberts, J., Roeger, W., Snudden, S., Trabandt, M. and In't Veld, J. (2012), "Effects of Fiscal Stimulus in Structural Models", American Economic Journal: Macroeconomics, 4(1), 22-68.

Coenen, G. and Straub, R. (2005), "Does Government Spending Crowd in Private Consumption? Theory and Empirical Evidence for the Euro Area", IMF Working Paper 
05/159, Washington D.C.: International Monetary Fund. Also ECB Working Paper Series No. 513, August, Frankfurt: European Central Bank.

Correia, I., Farhi, E., Nicolini, J.P. and Pedro Tele, P. (2013), "Unconventional Fiscal Policy at the Zero Bound", American Economic Review, 103(4), 1172-1211.

Davig, T. and Leeper, E.M. (2009), "Moneatry-Fiscal Policy Interactions", CAEPR Working Paper No. 010-2009. Available at: http://ssrn.com/abstract=1456355

Eggertsson, G. B. (2006), "Fiscal Multipliers and Policy Coordination”, Federal Reserve Bank of New York Staff Reports, No. 241, Federal Reserve Bank of New York: . New York.

Eggertsson, G. B. (2009), "What Fiscal Policy Is Effective at Zero Interest Rates?", Federal Reserve Bank of New York Staff Reports, No. 402, Federal Reserve Bank of New York: New York.

Eggertsson, G. B. (2011), "What Fiscal Policy is Effective at Zero Interest Rates?", NBER Macroeconomics Annual 2010, Vol. 25, 59-112; Edited by D. Asemoglu and M. Woodford, Chicago University Press: Chicago.

Estevão, M. and Samake, I. (2013), "The Economic Effects of Fiscal Consolidation with Debt Feedback", IMF Working Paper WP/13/136, May 2013, International Monetary Fund: Washington DC.

Freedman, C., Kumhof, M., Laxton, D., Muir, D. and Mursula, S. (2009), "Fiscal Stimulus to the Rescue? Short-run Benefits and Potential Long-run Costs of Fiscal Deficits", IMF Working Paper WP/09/255, International Monetary Fund: Washington DC.

Gechert, S. and Will, H. (2012), "Fiscal Multipliers: A Meta Regression Analysis", IMK Working Paper No. 97, July, Institut für Makroökonomie und Konjunkturforschung (IMK): Düsseldorf.

Godley, W. and Lavoie, M. (2007), "Fiscal Policy in a Stock-Flow Consistent (SFC) Model", Journal of Post Keynesian Economics, 30(1), 79-100. Reprinted in M. Lavoie and G. Zezza (eds.), (2012), The Stock-Flow Consistent Approach: Selected Writings of Wynne Godley, Palgrave Macmillan: Houndmills, Basingstoke..

Gravelle, J.G. and Hungerford, T.L. (2011), "Can Contractionary Fiscal Policy be Expansionary?”, Congressional Research Service, Report for Congress, R41849, Washington DC, 6 June 2011.

Hall, R.E. (2009), "By How Much Does GDP Rise if the Government Buys More Output?", Brookings Papers on Economic Activity, Fall 2009, pp. 183-231.

Hansen, S.G., Kashyap, A.K. and Stein, J.C. (2011), "A Macroprudential Approach to Financial Regulation”, Journal of Economic Perspectives, 25(1), 3-28.

Hein, E. and Truger , A. (2011), "Finance-Dominated Capitalism in Crisis: The Case for a Keynesian New Deal at the European and the Global Level", in P. Arestis and M. Sawyer (eds.), New Economics as Mainstream Economics, Palgrave Macmillan: Houndmills, Basingstoke. 
International Monetary Fund (IMF) (2010a), "A Fair and Substantial Contribution by the Financial Sector", Interim Report for the Meeting of the G20 Ministers, 16 April 2010, International Monetary Fund: Washington DC.

International Monetary Fund (IMF) (2010b), "Central Banking Lessons from the Crisis", Monetary and Capital Markets Department, 27 May 2010, International Monetary Fund: Washington DC.

International Monetary Fund (IMF) (2012a), "Fiscal Policy and the Real Exchange Rate", IMF Working Paper WP/12/52, International Monetary Fund: Washington DC.

International Monetary Fund (IMF) (2012b), "Balancing Fiscal Risks", Fiscal Monitor, World Economic and Financial Surveys, April, International Monetary Fund: Washington DC.

International Monetary Fund (IMF) (2013), "Reassessing the Role and Modalities of Fiscal Policy in Advanced Countries", IMF Policy Paper, September.

International Monetary Fund (IMF) (2014), “Fiscal Policy and Income Inequality", IMF Policy Paper, January.

In't Velt, J. (2003), "Fiscal Consolidations and Spillovers in the Euro Area Periphery and Core", Economic Papers, No. 506, October, European Economy: European Commission.

Jeanne, O. (2014), "Macroprudential Policies in a Global Perspective", NBER Working Paper 19967, National Bureau of Economic Research: Cambridge, MA. Linnemann, L. and Schabert, A. (2003), "Fiscal Policy in the New Neoclassical Synthesis", Journal of Money, Credit and Banking, 35(6), Part 1, 911-929.

Medina, J.P. and Roldós, J. (2014), "Monetary and Macroprudential Policies to Manage Capital Flows", IMF Working Papers 14/30, IMF Institute for Capacity Development, February.

Palley, T. I. (2011), “America's Flawed Paradigm: Macroeconomic Causes of the Financial Crisis and Great Recession", Empirica, 38 (1), 3-17). Originally published as "America's Exhausted Paradigm: Macroeconomic Causes of the Financial Crisis and Great Recession," New America Foundation: Washington, DC, July 2009.

Pennings,S. and Ruiz, E.P. (2013), "Fiscal Consolidations and Growth: Does Speed matter?", IMF Working Paper WP/13/230, International Monetary Fund: Washington DC.

Perotti, R. (2012), “The Effects of Tax Shocks on Output: Not So Large, But Not Small Either", American Economic Journal: Economic Policy, 4(2), 214-237.

Ramey, V.A. (2011), "Can Government Purchases Stimulate the Economy?" Journal of Economic Literature, 49(3), 673-85.

Ratto, M., Roeger, W. and In 't Velt, J. (2008), QUEST III: An Estimated DSGE Model of the Euro Area with Fiscal and Monetary Policy", Economic Papers, No. 335, July, European Economy: European Commission.

Romer, C.D. and Romer, D.H. (2010), "The Macroeconomic Effects of Tax Changes: Estimates Based on a New Measure of Fiscal Shocks, American Economic Review, 100(3), 763-801. 
Sawyer, M. (2010), "Budget Deficits and Reductions in Inequality for Economic Prosperity: A Kaleckian Analysis", Revista LEBRET, No. 2, 31-44.

Siesman, T. and Watzka, S. (2013), "Fiscal Multipliers and the Choice of Zero Lower Bound Modeling", CESifo Working Paper No. 4342. Available at: www.CESifo-group.org/wp

Sly, N. and Weber, C. (2013), "International Fiscal Policy Coordination and GDP Comovement", CESifo Working Paper No. 4358. Available at: www.CESifo-group.org/wp

Van Treeck, T. and Sturn, S. (2012), "Income Inequality as a Cause of the Great Recession? A Survey of the Current Debates", ILO Conditions of Work and Employment Series No. 39, ILO: Geneva.

Woo, J., Bova, E., Kinda, T. And Zhang, Y.S. (2013), "Distributional Consequences of Fiscal Consolidation and the Role of Fiscal Policy: What do the Data Say?", IMF Working Paper WP/13/195, International Monetary Fund: Washington DC.

Woodford, M. (2010), "Simple Analytics of the Government Expenditure Multiplier". Available at: http://www.columbia.edu/ mw2230/G_ASSA.pdf

Woodford, M. (2011), "Simple Analytics of the Government Expenditure Multiplier", American Economic Journal: Macroeconomics, 3(1), 1-35. 